\title{
QacE and QacE $\Delta 1$ Genes and Their Correlation to Antibiotics and Biocides Resistance Pseudomonas aeruginosa
}

\author{
Zeinab H Helal ${ }^{1,2}$ and Mazhar I Khan ${ }^{2}$ \\ ${ }^{1}$ Department of Microbiology and Immunology, Faculty of Pharmacy, Al-Azhar University, Cairo, Egypt \\ ${ }^{2}$ Department of Pathobiology and Veterinary science, University of Connecticut, Storrs, CT 06269, USA \\ *Corresponding Author \\ Mazhar I Khan \\ Department of Pathobiology and Veterinary science \\ University of Connecticut \\ Storrs, CT 06269 \\ USA \\ E-mail: mazhar.khan@uconn.edu \\ zeinabhelal@hotmail.com (Zeinab H Helal)
}

Received: 28 February 2015; | Revised: 23 April 2015; | Accepted: 13 May 2015

\begin{abstract}
One of the serious and growing challenges for infection control programs worldwide is hospital acquired infections. Pseudomonas aeruginosa is considered the most common cause of hospital acquired Gramnegative infections. Intensive exposure of hospital pathogens to biocides may result in the emergence of resistance not only to the biocides, but possibly to antibiotics as well. Thus, the current study was done to investigate the prevalence of $q a c E \Delta l$ and $q a c E$ genes and their correlation to antibiotics and biocides resistance in Pseudomonas aeruginosa isolated in Egypt. The antimicrobial activity of six biocides against drug sensitive and multi-drug resistant Pseudomonas aeruginosa was evaluated. Phenol and formalin displayed a higher antimicrobial activity compared to other biocides tested. Minimum inhibitory concentration (MIC) values of chlorine releasing agents were higher than the dilution prescribed by their manufactures. The qacE $\triangle 1$ gene was identified in $57.8 \%$ of multidrug resistant isolates and $21.4 \%$ in susceptible strains, While, qacE gene was only detected among multi-drug resistant Pseudomonas aeruginosa. This study reported a correlation between qacE 1 and multidrug resistance Pseudomonas aeruginosa, while there was no correlation between the presence of qac genes and increased MIC values to biocides. The effectiveness of biocides is very important to control microbial population and prevent the transmission of infections in hospitals. In conclusion we highlight the need for health care facilities to assess the antimicrobial effectiveness of biocides periodically.
\end{abstract}

Keywords: Biocides, MIC, qacE, qacE $\Delta 1$ and $P$. aeruginosa. 


\section{Introduction}

Biocides, including disinfectants and antiseptics, are used for a variety of topical and hard surface applications in health care facilities [1]. Biocides have an important role in preventing and controlling hospital-acquired infections. However, failures in the antimicrobial activities of biocides have been reported [2,3]. Generally, the susceptibility of Gram-negative bacteria is lower than gram-positive bacteria. This outcome is likely to be intrinsic rather than plasmid mediated, due to the protective barrier of the outer membrane [4].

Due to its ability to survive in unfavorable environmental conditions, biofilm formation and its high resistance to antibiotics, antiseptics, and disinfectants, Pseudomonas aeruginosa remains to be an important bacterium in nosocomial infections $[5,6,7,8]$. It can infect multiple organ systems and can cause serious illness, especially among the immunocompromised [9]. One of the mechanisms of resistance to biocide is the expression of efflux systems. $P$. aeruginosa harbors multidrug transporter efflux systems, involving QacE and QacE $\Delta 1$, as do other Gramnegative bacteria $[10,11]$. The qacE $I$ gene is a defective form of the qacE gene and is included in the $3^{\prime}$ conserved segment of class I integrin as described by Paulsen et al., [12, 13].

The possibility of $P$. aeruginosa developing resistance to biocide formulations, as they do with antibiotics, underscores the need to continuously evaluate the antimicrobial activities of various biocide formulations against this pathogen. In Egypt, investigations regarding the determinants of resistance and susceptibility to biocides at their currently prescribed concentrations are very confined. Resistance to antimicrobial agents is usually tested as minimum inhibitory concentration (MIC), which is a very useful investigation tool [2]. The purpose of this work was to study the susceptibility of multidrug resistant (MDR) P. aeruginosa, to commonly used biocides and to find out the distribution of the qacE $\Delta$ land $q a c E$ gene markers in $P$. aeruginosa isolates and their correlation to antimicrobial resistance.

\section{Materials and Methodology}

In this study, one hundred and thirty-six clinical isolates of $P$. aeruginosa were used. The isolates were isolated from different specimens submitted to the Microbiology Laboratory, Clinical Pathology Department, Ain Shams University Hospital for routine culture. All the isolates were characterized and identified according to standard techniques [14]. Isolates were examined for antimicrobial susceptibility using the disk diffusion method as described by Kirby Bauer according to the CLSI [15].

The antibiotic panel included : piperacillin (PC,100 $\mu \mathrm{g})$, ticarcillin/clavulinic acid (TC,75/10 $\mu \mathrm{g})$, piperacillin/ tazobactam (PT, $100 \mu \mathrm{g} / 10 \mu \mathrm{g}$ ), cefoperazone $(\mathrm{CZ}, 30 \mu \mathrm{g})$, cefotaxime (CFO, 30 $\mu \mathrm{g})$, cefepime (CPM, $30 \mu \mathrm{g})$, ceftriaxone (CT, 30 $\mu \mathrm{g})$, ceftazidime (CAZ, $30 \mu \mathrm{g})$, imipenem (IMP, $10 \mu \mathrm{g}$ ), amikacin (AK, $30 \mu \mathrm{g})$, gentamicin (GN, $10 \mu \mathrm{g}$ ), ciprofloxacin (CIP, $5 \mu \mathrm{g}$ ), levofloxacin (LEF, $5 \mu \mathrm{g}$ ), and chloramphenicol (CMP, $30 \mu \mathrm{g}$ ). Resistance to each antibiotic was recorded, and isolates resistant to one antimicrobial agent in the three or more anti-pseudomonal antimicrobial classes (penicillin/cephalosporins, carbapenems, fluoroquinolones, and aminoglycosides) were defined as MDR [16].

The MDR isolates $(n=38)$ plus 14 sensitive isolates were tested for biocide susceptibility by the broth macro-dilution method. Fresh colonies obtained after overnight subculture were suspended in $10 \mathrm{ml} 0.85 \%$ saline to prepare the inoculum. The inoculum suspension was adjusted to match the turbidity of $0.5 \mathrm{McFarland}$ standards [15].

The biocides selected for testing were the following chemical disinfectants/antiseptics recommended for patient care items and instruments: sodium dichloroisocyanurate (sodium troclosene) (SaniTab tablets 4.72gm); sodium hypochlorite solution (10\% w/v, $\mathrm{pH} 7)$; formalin $(37 \% \mathrm{w} / \mathrm{v})$; aqueous povidone-iodine $\left(10 \% \mathrm{w} / \mathrm{v}, \quad \mathrm{PVP}-\mathrm{I}_{2}\right)$ solution; chlorhexidine digluconate $(0.3 \%)$ /cetrimide $(3 \%)$ (Savlon) and phenol $(10 \% \mathrm{w} / \mathrm{v})$ solution. Broth macro-dilution 
method was used to determine the MICs of the biocides as described by Mazzola et al.,[17], starting from the initial concentrations, as shown in Table 1. Each disinfectant solution was diluted by the serial twofold dilution method using Mueller Hinton broth. All tubes except the negative control tube were inoculated with $0.1 \mathrm{ml}$ of the prepared inoculum adjusted to 0.5 McFarland standards. The positive control tube contained $0.1 \mathrm{ml}$ inoculum in $1 \mathrm{ml}$ Mueller
Hinton broth with evidence of bacterial growth (turbidity). The negative control tube contained Mueller Hinton broth and the disinfectant to be tested with no evidence of bacterial growth (clear). The tubes were incubated at $37^{\circ} \mathrm{C}$ for 18 $24 \mathrm{hrs}$. After the incubation period, the tubes were examined and the MIC was identified as the lowest concentration of the disinfectant had no visible bacterial growth.

Table 1. Biocide Agents, their Started Concentrations and Dilutions Used for MIC Test

\begin{tabular}{|l|c|c|c|c|}
\hline Chemical agents & $\begin{array}{c}\text { Commercial } \\
\text { name }\end{array}$ & $\begin{array}{c}\text { Recommended } \\
\text { dilution }\end{array}$ & $\begin{array}{c}\text { Starting } \\
\text { concentration }\end{array}$ & Dilution \\
\hline $\begin{array}{l}\text { Chlorhexidine( } \\
\text { Ch)/ } \\
\text { Cetrimide (C) }\end{array}$ & Savlon & $3.3 \%$ & $\begin{array}{c}3.3 \%(0.3 \% \mathrm{Ch}, \\
3 \% \mathrm{C})\end{array}$ & $1.65 \%, 0.825 \%, 0.4125 \%$ and $0.206 \%$ \\
\hline Povidone-iodine & Betadine & $5 \%$ & $10 \%$ & $5 \%, 2.5 \%, 1.25 \%$ and $0.625 \%$ \\
\hline $\begin{array}{l}\text { Sodium } \\
\text { hypochlorite }\end{array}$ & $\begin{array}{c}\text { Sodium } \\
\text { hypochlorite }\end{array}$ & $0.5 \%$ & $10 \%$ & $5 \%, 2.5 \%, 1.25 \%, 0.625 \%$ and $0.312 \%$ \\
\hline $\begin{array}{l}\text { Sodium } \\
\text { troclosene }\end{array}$ & Sanitab & $0.3 \%$ & $10 \%$ & $\begin{array}{l}5 \%, 2.5 \%, 1.25 \%, 0.625 \%, 0.312 \%, 0.156 \% \\
\text { and } 0.078 \%\end{array}$ \\
\hline Phenol & Phenol & $1-5 \%$ & $10 \%$ & $\begin{array}{l}5 \%, 2.5 \%, 1.25 \%, 0.625 \%, 0.312 \% \text { and } 0.156 \\
\%\end{array}$ \\
\hline Formalin & Formalin & $0.2-8 \%$ & $9.25 \%$ & $\begin{array}{l}4.625 \%, 2.312 \%, 1.156 \%, 0.578 \%, 0.289 \%, \\
0.145 \%, 0.0725 \%, 0.036 \% \text { and } 0.018 \%\end{array}$ \\
\hline
\end{tabular}

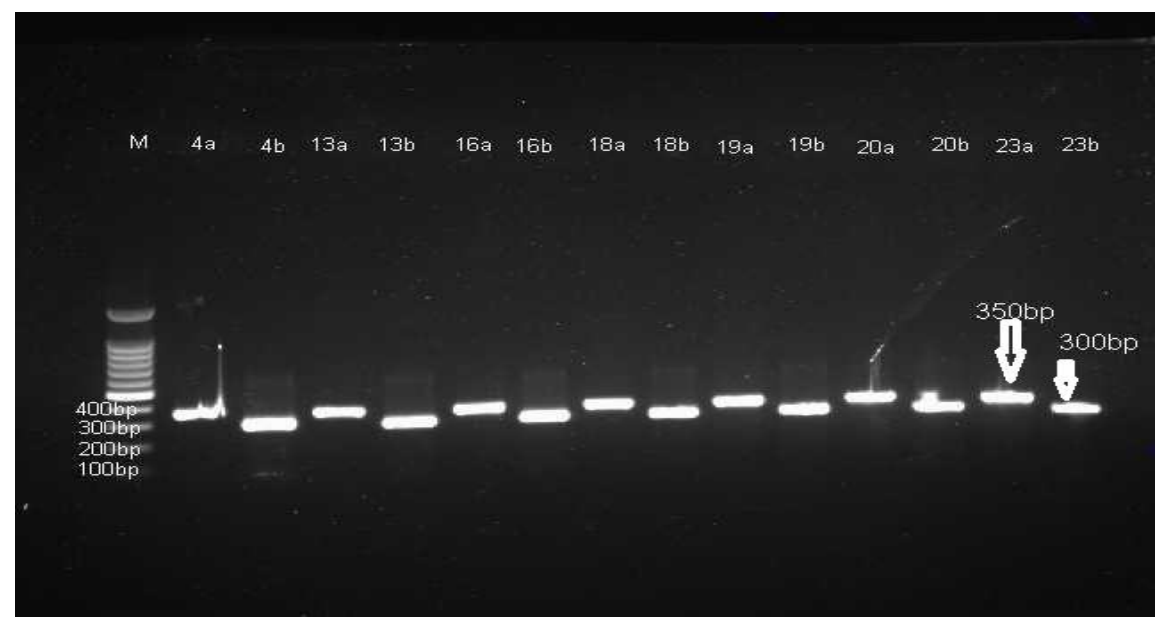

Fig. 1- Gel electrophoresis of the PCR amplified product for detection of qacE and qacE 1 genes. M: $100 \mathrm{bp}$ DNA ladder, lanes 4a, 13a, 16a, 18a, 19a, 20a and 23a positive samples for qacE gene (350 bp); lanes 4b, 13b, $16 \mathrm{~b}, 18 \mathrm{~b}, 19 \mathrm{~b}, 20 \mathrm{~b}$ and 23b: positive samples for qacE 1 gene (300 bp) 
The qacE $\Delta l$ and $q a c E$ resistance genes were amplified by Polymerase chain reaction (PCR). DNAs were extracted using a Genomic DNA Extraction Kit (Fermentas; Life Science, Waltham, MA) in accordance with manufacturer instructions. To amplify qacE gene, PCR was done using 10 pmol from each forward (5 CCCGAATTCATGAAAGGCTGGCTT-3') and reverse (5'-TAAGCTTTCACCATGGCGTCGG$\left.3^{\prime}\right)$ specific qacE primers, which amplify $350 \mathrm{bp}$ fragments (Figure 1). The qacE $\Delta l$ gene was detected by using the same PCR conditions, with the exception of 10 pmol from each forward (5'TAGCGAGGGCTTTACTAAGC-3') and reverse (5'-ATTCAGAATGCCGAACACCG-3') specific qacE 1 primers, which amplify $300 \mathrm{bp}$ fragments (Figure 1). The primers, described by Kücken et al. [18] and Wang et al. [19], were prepared by Invitrogen (Grand Island, NY). To perform the PCR, GoTaq Green Master Mix (Promega, Madison, WI) was used in the PCR assay. DNA was amplified according to the following conditions; 120 s of denaturation at $93^{\circ} \mathrm{C}$ followed by 35 cycles of $30 \mathrm{~s}$ at $93^{\circ} \mathrm{C} ; 30 \mathrm{~s}$ at $55^{\circ} \mathrm{C} ; 60 \mathrm{~s}$ at $72^{\circ} \mathrm{C}$; and finally, $5 \mathrm{~min}$ at $72^{\circ} \mathrm{C}$. The PCR products were separated through a $1.5 \%$ agarose gel by electrophoresis. The Chi-square test was applied to analyze results.

\section{Results}

Fourteen $(10.3 \%)$ out of 136 isolates of $P$. aeruginosa were susceptible to all antibiotics used, while, $89.7 \%$ of the isolates were resistant to one or more antimicrobial agents. With respect to the total number of resistant strains, $34.4 \%$ were MDR. Table 2 shows the antibiotic susceptibility patterns of the 136 isolates of $P$. aeruginosa.

Imipenem was the most effective antibiotic tested against $P$. aeruginosa isolates and showed the maximum sensitivity (66.2\%), followed by amikacin (63.2\%) and ciprofloxacin (55.1\%), whereas the $P$. aeruginosa isolates were highly resistant to chloramphenicol (78\%), followed by cefepime $(75.7 \%)$ then ceftriaxone $(64.7 \%)$.

One hundred and twenty two $P$. aeruginosa isolates were categorized into 41 different antibiotypes. Table 3 presents antibiotypes 1-11, including 68 strains that were the most prevalent antibiotypes. Thirty-eight MDR $P$. aeruginosa isolates were subjected to biocide susceptibility testing and were categorized as antibiotypes 1, 2, 4, and 7 (Table 3).

In the present study, both sensitive and MDR $P$. aeruginosa isolates were effectively inhibited by the user's defined concentrations of PVP- $\mathrm{I}_{2}$, Savlon, phenol, and formalin. However, the clinical MDR $P$. aeruginosa had statistically significant MICs to PVP-I $\mathrm{I}_{2}$ and Savlon $(\mathrm{p}<0.05)$. No significant differences in formalin or phenol MICs were found between the two groups. A low formalin concentration, $0.018 \%$, effectively inhibited the growth of all of the sensitive $P$. aeruginosa and more than $60 \%$ of the MDR $P$. aeruginosa strains. On the other hand, both $P$. aeruginosa groups were inhibited by a phenol concentration $\leq 1.25 \%$. Both $P$. aeruginosa groups had MICs exceeding the user's defined concentration of sodium hypochlorite and SaniTab. The MDR $P$. aeruginosa had statistically significant MICs to sodium hypochlorite and SaniTab $(\mathrm{p}<0.05)$.

The distribution of $q a c E$ and qacE $\Delta l$ genes is presented in Table 5. Out of $52 P$. aeruginosa isolates, $13.4 \%$ contained qacE and $47.2 \%$ contained qacE$\Delta 1$. The prevalence differed between pseudomonas groups: qacE $\Delta l$ detected in $57.9 \%$ of the MDR P. aeruginosa isolates and $21.4 \%$ of the sensitive strains, and qacE detected in $18.4 \%$ of the MDR strains and in none of the sensitive strains. Concomitant expression of the $q a c E$ and $q a c E \Delta l$ genes occurred in seven of 38 (18.4\%) of the MDR isolates; no isolates from the sensitive group had concomitant expression of both genes. Table 6 presents the occurrence of qacEAl and the MICs of the biocides. 
Table 2. Antibiotic Susceptibility of Clinical $P$. aeruginosa Isolates

\begin{tabular}{|l|c|c|c|c|c|c|}
\hline Antibiotic & Resistant & & Intermediate & & Susceptible & \\
\hline & Number & $\%$ & Number & $\%$ & Number & $\%$ \\
\hline Piperacillin & 74 & 54.4 & 0 & 0 & 62 & 45.6 \\
\hline Piperacillin/tazobactam & 74 & 54.4 & 0 & 0 & 62 & 45.6 \\
\hline $\begin{array}{l}\text { Ticarcillin/ clavulinic } \\
\text { acid }\end{array}$ & 84 & 61.8 & 1 & 0.7 & 51 & 37.5 \\
\hline Cefoperazone & 75 & 55.1 & 10 & 7.4 & 51 & 37.5 \\
\hline Cefotaxime & 83 & 61 & 14 & 10.3 & 39 & 28.7 \\
\hline Ceftriaxone & 88 & 64.7 & 7 & 5.1 & 41 & 30.2 \\
\hline Ceftazidime & 77 & 56.6 & 9 & 6.6 & 50 & 36.8 \\
\hline Cefepime & 103 & 75.7 & 6 & 4.4 & 27 & 19.9 \\
\hline Imipenem & 22 & 16.1 & 24 & 17.7 & 90 & 66.2 \\
\hline Amikacin & 40 & 29.4 & 10 & 7.4 & 86 & 63.2 \\
\hline Gentamicin & 55 & 40.4 & 20 & 14.7 & 61 & 44.9 \\
\hline Ciprofloxacin & 49 & 36 & 8 & 5.9 & 75 & 55.1 \\
\hline Levofloxacin & 56 & 41.2 & 27 & 19.9 & 53 & 38.9 \\
\hline Chloramphenicol & 106 & 78 & 11 & 8.1 & 19 & 13.9 \\
\hline
\end{tabular}

Table 3. Groups of Clinical P.aeruginosa Isolates that Have the Same Antibiotype

\begin{tabular}{|l|l|l|}
\hline Profile & Number of isolates & Resistance pattern \\
\hline $\mathbf{1}(\mathbf{1 4})$ & 16 & PC- PT- TC- CZ-CFO- CT- CAZ- CPM -IMP- AK- GN - CIP- LEF- CMP \\
\hline $\mathbf{2 ( 1 3 )}$ & 12 & PC- PT- TC- CZ-CFO- CT- CAZ- CPM - AK- GN - CIP- LEF- CMP \\
\hline $\mathbf{3 ( 1 1 )}$ & 11 & PC- PT- TC- CZ-CFO- CT- CAZ- CPM - CIP- LEF- CMP \\
\hline $\mathbf{4 ( 1 2 )}$ & 6 & PC- PT- TC- CZ-CFO- CT- CAZ- CPM - AK- GN - LEF- CMP \\
\hline $\mathbf{5 ( 1 0 )}$ & 6 & PC- PT- TC- CZ-CFO- CT- CAZ- CPM - GN - CMP \\
\hline $\mathbf{6 ( 1 0 )}$ & 4 & PC- PT- TC- CZ-CFO- CT- CAZ- CPM - LEF- CMP \\
\hline $\mathbf{7 ( 1 3 )}$ & 4 & PC- PT- TC- CZ-CFO- CT- CAZ- CPM -IMP- AK- GN - LEF- CMP \\
\hline $\mathbf{8 ( 1 0 )}$ & 3 & PC- PT- TC- CZ-CFO- CT- CAZ- CPM -IMP - CMP \\
\hline $\mathbf{9 ( 1 0 )}$ & 2 & PC- PT- TC- CZ-CFO- CT- CAZ- CPM - CIP- CMP \\
\hline $\mathbf{1 0}(\mathbf{8})$ & 2 & PC- PT- TC-CFO- CAZ- CPM - GN - CMP \\
\hline $\mathbf{1 1}(\mathbf{4})$ & 2 & CFO- CPM -CIP - CMP \\
\hline
\end{tabular}


Table 4. Distribution of MICs of Biocides among $P$. aeruginosa Isolates

\begin{tabular}{|c|c|c|c|c|c|c|}
\hline \multirow{2}{*}{$\begin{array}{l}\text { Chemical } \\
\text { agent }\end{array}$} & \multirow{2}{*}{$\begin{array}{l}\text { MIC } \\
\text { mg/L }\end{array}$} & \multirow[t]{2}{*}{$\%$} & \multicolumn{2}{|c|}{ P. aeruginosa Group } & \multirow{2}{*}{$\begin{array}{l}\text { Chi- } \\
\text { square }\end{array}$} & \multirow{2}{*}{$\begin{array}{c}\text { P value } \\
\text { (Significant) }\end{array}$} \\
\hline & & & MDR $(n=38)$ & $\begin{array}{c}\text { Sensitive } \\
(\mathrm{n}=14)\end{array}$ & & \\
\hline \multirow[t]{4}{*}{ PVP-I $\mathbf{I}_{2}$} & 50000 & $5 \%$ & $9(23.6 \%)$ & 0 & \multirow[t]{4}{*}{23.4804} & \multirow[t]{4}{*}{ Significant at $\mathrm{p}<0.05$} \\
\hline & 25000 & $2.5 \%$ & 0 & $7(50 \%)$ & & \\
\hline & 12500 & $1.25 \%$ & $15(39.4 \%)$ & $3(21.4 \%)$ & & \\
\hline & 6250 & $0.625 \%$ & $14(36.8 \%)$ & $4(28.6 \%)$ & & \\
\hline \multirow[t]{6}{*}{ Savlon } & 33000 & $3.3 \%$ & $6(15.8 \%)$ & $1(7.1 \%)$ & \multirow[t]{6}{*}{35.254} & \multirow[t]{6}{*}{ Significant at $\mathrm{p}<0.05$} \\
\hline & 16500 & $1.65 \%$ & $3(7.8 \%)$ & 0 & & \\
\hline & 8250 & $0.825 \%$ & $6(15.8 \%)$ & 0 & & \\
\hline & 4125 & $0.412 \%$ & $13(34.2 \%)$ & $3(21.4 \%)$ & & \\
\hline & 2062.5 & $0.206 \%$ & $10(26.3 \%)$ & 0 & & \\
\hline & 1031.25 & $0.103 \%$ & 0 & $10(71.4 \%)$ & & \\
\hline \multirow[t]{5}{*}{ Hypochlorite } & 50000 & $5 \%$ & $3(7.8 \%)$ & 0 & \multirow[t]{5}{*}{22.618} & \multirow[t]{5}{*}{ Significant at $p<0.05$} \\
\hline & 25000 & $2.5 \%$ & $12(31.5 \%)$ & $1(7.1 \%)$ & & \\
\hline & 12500 & $1.25 \%$ & $17(44.7 \%)$ & $3(21.4 \%)$ & & \\
\hline & 6250 & $0.625 \%$ & $3(7.8 \%)$ & 0 & & \\
\hline & 3125 & $0.312 \%$ & $3(7.8 \%)$ & $10(78.5 \%)$ & & \\
\hline \multirow{4}{*}{ Phenol } & 12500 & $1.25 \%$ & $7(13.11 \%)$ & $2(14.3 \%)$ & \multirow[t]{4}{*}{5.7191} & \multirow[t]{4}{*}{ Not significant at $\mathrm{p}<0.05$} \\
\hline & 6250 & $0.625 \%$ & $4(7.8 \%)$ & $2(14.3 \%)$ & & \\
\hline & 3125 & $0.312 \%$ & 0 & $1(7.1 \%)$ & & \\
\hline & 1562.5 & $0.156 \%$ & $27(71 \%)$ & $9(64.3 \%)$ & & \\
\hline \multirow[t]{5}{*}{ Sanitab } & 100000 & $10 \%$ & $19(50 \%)$ & 0 & \multirow[t]{5}{*}{23.7627} & \multirow[t]{5}{*}{ Significant at $\mathrm{p}<0.05$} \\
\hline & 25000 & $2.5 \%$ & 0 & $3(21.4 \%)$ & & \\
\hline & 12500 & $1.25 \%$ & $7(13.1 \%)$ & $2(14.3 \%)$ & & \\
\hline & 1562.5 & $0.156 \%$ & 0 & $3(21.4 \%)$ & & \\
\hline & 781.25 & $0.078 \%$ & $12(31.5 \%)$ & $6(42.9 \%)$ & & \\
\hline \multirow{6}{*}{ Formalin } & 578.125 & $0.578 \%$ & 0 & 0 & \multirow[t]{6}{*}{7.767} & \multirow[t]{6}{*}{ Not significant at $p<0.05$} \\
\hline & 289 & $0.289 \%$ & $4(10.5 \%)$ & 0 & & \\
\hline & 144.5 & $0.144 \%$ & $4(10.5 \%)$ & 0 & & \\
\hline & 72.26 & $0.072 \%$ & $4(10.5 \%)$ & 0 & & \\
\hline & 36.132 & $0.036 \%$ & $3(7.8 \%)$ & 0 & & \\
\hline & 18.066 & $0.018 \%$ & $23(60.5 \%)$ & $100 \%)$ & & \\
\hline
\end{tabular}

Table 5. Incidence of $q a c E$ and $q a c E \Delta l$ Genes among Isolates of $P$. aeruginosa.

\begin{tabular}{|c|c|c|c|c|c|}
\hline Gene & & $\begin{array}{l}\text { MDR } \\
(\mathbf{n}=38)\end{array}$ & $\begin{array}{l}\text { Sensitive } \\
(\mathrm{n}=14)\end{array}$ & $\begin{array}{l}\text { Chi- } \\
\text { square }\end{array}$ & $P$ value \\
\hline \multirow[t]{3}{*}{ qacE } & Positive & 7 & 0 & \multirow[t]{3}{*}{2.9801} & \multirow[t]{3}{*}{ Significant at $\mathrm{p}<0.05$} \\
\hline & Negative & 31 & 14 & & \\
\hline & Total & 38 & 14 & & \\
\hline \multirow[t]{3}{*}{ qacE $\Delta I$} & Positive & 22 & 3 & \multirow[t]{3}{*}{5.4499} & \multirow{3}{*}{$\begin{array}{c}\text { Not significant at } \mathrm{p}< \\
0.05\end{array}$} \\
\hline & Negative & 16 & 11 & & \\
\hline & Total & 38 & 14 & & \\
\hline \multirow[t]{3}{*}{$q a c E+q a c E \Delta I$} & Positive & 7 & 0 & & \\
\hline & Negative & 31 & 14 & & \\
\hline & Total & 38 & 14 & & \\
\hline
\end{tabular}


Table 6. MIC of Biocides and Association with qacE $\Delta l$ Gene

\begin{tabular}{|c|c|c|c|c|c|}
\hline Chemical agents & $\begin{array}{c}\mathrm{MIC} \\
\mathrm{mg} / \mathrm{ml}\end{array}$ & $\%$ & $\begin{array}{c}\text { Positive strains of } \\
\text { qacE } \Delta 1(\%)\end{array}$ & $\begin{array}{c}\text { Negative strains of } \\
\text { qacE } \Delta 1(\%)\end{array}$ & Total \\
\hline \multirow{4}{*}{ PVP-I $\mathbf{I}_{2}$} & 50000 & $5 \%$ & $4(44.4 \%)$ & $5(55.6 \%)$ & 9 \\
\hline & 25000 & $2.5 \%$ & $2(28.6 \%)$ & $5(71.4 \%)$ & 7 \\
\hline & 12500 & $1.25 \%$ & $12(66.7 \%)$ & $6(33.3 \%)$ & 18 \\
\hline & 6250 & $0.625 \%$ & $7(38.8 \%)$ & $11(61.2 \%)$ & 18 \\
\hline \multirow{6}{*}{ Savlon } & 33000 & $3.3 \%$ & $4(57.1 \%)$ & $3(42.9 \%)$ & 7 \\
\hline & 16500 & $1.65 \%$ & $2(66.7 \%)$ & $1(33.3 \%)$ & 3 \\
\hline & 8250 & $0.825 \%$ & $4(66.7 \%)$ & $2(33.3 \%)$ & 6 \\
\hline & 4125 & 0.412 & $10(62.5 \%)$ & $6(37.5 \%)$ & 16 \\
\hline & 2062.5 & 0.206 & $5(50 \%)$ & $5(50 \%)$ & 10 \\
\hline & 1031.25 & 0.103 & $0(0 \% 0)$ & $10(100 \%)$ & 10 \\
\hline \multirow[t]{5}{*}{ Hypochlorite } & 50000 & $5 \%$ & $2(66.7 \%)$ & $1(33.3 \%)$ & 3 \\
\hline & 25000 & $2.5 \%$ & $10(76.9 \%)$ & $3(23.1 \%)$ & 13 \\
\hline & 12500 & $1.25 \%$ & $11(55 \%)$ & $9(45 \%)$ & 20 \\
\hline & 6250 & $0.625 \%$ & $1(33.3 \%)$ & $2(66.7 \%)$ & 3 \\
\hline & 3125 & 0.312 & $1(7.7 \%)$ & $12(92.3 \%)$ & 13 \\
\hline \multirow[t]{4}{*}{ Phenol } & 12500 & $1.25 \%$ & $7(77.7 \%)$ & $2(22.3 \%)$ & 9 \\
\hline & 6250 & $0.625 \%$ & $1(16.6 \%)$ & $5(83.4 \%)$ & 6 \\
\hline & 3215 & $0.312 \%$ & $1(100 \%)$ & $0(0 \%)$ & 1 \\
\hline & 1562.5 & $0.156 \%$ & $16(44.4 \%)$ & $20(55.6 \%)$ & 36 \\
\hline \multirow[t]{5}{*}{ Sanitab } & 100000 & $10 \%$ & $9(47.3 \%)$ & $10(52.7 \%)$ & 19 \\
\hline & 25000 & $2.5 \%$ & $1(33.3 \%)$ & $2(66.7 \%)$ & 3 \\
\hline & 12500 & $1.25 \%$ & $7(77.7 \%)$ & $2(22.3 \%)$ & 9 \\
\hline & 1562.5 & $0.156 \%$ & $0(0 \%)$ & $3(100 \%)$ & 3 \\
\hline & 781.25 & $0.078 \%$ & $8(44.4 \%)$ & $10(55.6 \%)$ & 18 \\
\hline \multirow[t]{5}{*}{ Formalin } & 289 & $0.289 \%$ & $2(50 \%)$ & $2(50 \%)$ & 4 \\
\hline & 144.5 & $0.144 \%$ & $4(100 \%)$ & $0(0 \%)$ & 4 \\
\hline & 72.26 & $0.072 \%$ & $4(100 \%)$ & $0(0 \%)$ & 4 \\
\hline & 36.123 & $0.036 \%$ & $3(100 \%)$ & $0(0 \%)$ & 3 \\
\hline & 18.066 & $0.018 \%$ & $12(32.4 \%)$ & 25 (67.6) & 37 \\
\hline
\end{tabular}

\section{Discussion}

In recent years, $P$. aeruginosa emerged in Egypt and it is seen mainly in hospital acquired infections [20, 21, 22]. The standard definition of MDR is an acquired non-susceptibility to at least one agent in three or more antimicrobial categories [16]. In our study, we demonstrated that $34.4 \%$ of the $P$. aeruginosa isolates were MDR. Similar reports of MDR $P$. aeruginosa have been documented previously [21, 23, 24].

The resistance to commonly used antimicrobial agents by $P$. aeruginosa is reportedly increasing worldwide and is considered a public health threat $[21,25,26]$. In this study $P$. aeruginosa isolates were highly resistant to all antibiotic tested except imipenem and amikacin. The effectiveness of imipenem and amikacin against $P$. aeruginosa has also been reported by other studies [8, 21, 24, 27, 28, 29]. The resistance pattern of $P$. aeruginosa to quinolones observed in the present study was similar to other results reported [21, 24]. We noticed that, among cephalosporin, a high resistance rate was exhibited against cefepime and cefotriaxone, which was consistent with other reports [20, 21, 30]. In contrast, earlier studies have reported cefepime to be the most effective antimicrobial agent against $P$. aeruginosa [31, 32-33]. However, this contradiction may be due to the continuous evolution of MDR strains worldwide.

Biocides have been widely used to minimize the spread of infections by MDR organisms [34, 
35], however the emerging resistance to biocides has prompted the need for more research into biocide efficacy $[27,36]$. Although $P$. aeruginosa resistance to biocides has been extensively studied, this is the first study to report on biocide activity against this bacterium in Egypt.

Formaldehyde, phenols, PVP-I $\mathrm{I}_{2}$, Savlon, and chloride-releasing agents are widely used as disinfectants in hospitals. In this study, we verified that formalin, phenols, PVP-I ${ }_{2}$, and Savlon were effective when tested against clinical isolates of $P$. aeruginosa according to the user's defined concentration. We found that formalin and phenol were the most effective biocidic agents in the present study due to the fact that no significant differences were found between the sensitive and MDR $P$. aeruginosa groups regarding the MICs of formalin and phenol.

Lower concentrations of Savlon were found to be effective against $92.8 \%$ and $84.2 \%$ of the drug-susceptible and MDR isolates of $P$. aeruginosa respectively. Comparable findings were reported in studies conducted in Nigeria and Ethiopia [28, 37]. We demonstrated that lower dilutions of $\mathrm{PVP}-\mathrm{I}_{2}$ were effective against $100 \%$ of the drug-sensitive group and $76.4 \%$ of the MDR group. Clinical MDR $P$. aeruginosa had statistically significant MICs to $\mathrm{PVP}-\mathrm{I}_{2}$ and Savlon $(\mathrm{p}<0.05)$.

This data proved that multidrug resistant Pseudomonas aeruginosa are not necessarily more resistant to biocides like Savlon, Povidoneiodine, phenol and formalin than antibiotic sensitive strains.

In this study, resistance was observed with some biocide formulations at the dilution prescribed by their manufactures. Studies in USA and Brazil reported that the recommended user dilution with $0.5 \%$ of sodium hypochlorite was effective against $92.2 \%$ and $86 \%$, of $P$. aeruginosa isolates respectively [3. 38]. In contrast, in our study $69.2 \%$ and $59.6 \%$ of $52 P$. aeruginosa isolates examined were resistant to the user's defined concentrations of hypochlorite and SaniTab respectively. This may be attributed to the extensive use of this type of disinfectant in the routine infection control in Egypt.

Both $q a c A$ and $q a c E$ were the first reported $q a c$-mediated resistance genes to be involved in the efflux-based system [39, 40]. Subsequently, an energy-dependent efflux pump that relies on the proton motive force was assured as a mechanism of resistance conferred by the qac genes [41, 42]. The clinical importance of qacmediated resistance is primarily attributed to biocides resistance [43].

We examined the presence of the qacE and qacE $\Delta 1$ genes in $52 P$. aeruginosa clinical isolates. The percentages of positive strains for

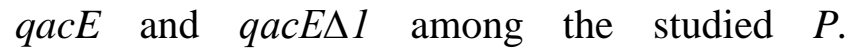
aeruginosa were $13.5 \%$ and $48 \%$ respectively. This corresponds to other reports which have recorded higher percentages of qacE $I$ compared to $q a c E[10,18,27]$. In our study, there were statistical significant differences in detection of the qacEDl gene between the MDR and susceptible strains. The qacE 1 gene was found in 22 of $38(57.8 \%)$ MDR isolates and in three of $14(21.4 \%)$ sensitive strains. However, there was no significant difference in detection of the $q a c E$ gene between the MDR and drug-sensitive $P$. aeruginosa isolates. Our results indicated that the

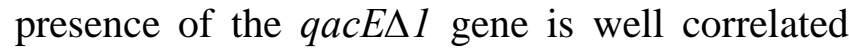
with multidrug resistance, consistent with the results of other studies $[19,27]$. The results of our experiments agree with the results of other groups $[10,44]$ in which all of the qacE positive strains were also positive for $q a c E \Delta 1$.

In conclusion, we observed biocide resistance in MDR $P$. aeruginosa isolates examined in this study. Our data indicates that $q a c E \Delta 1$ and $q a c E$ are not directly correlated with increased biocide MICs; however the qacE $\Delta I$ gene was detected at higher percentages in less susceptible isolates of $P$. aeruginosa. As aforementioned, the qacE gene was detected much less frequently and invariable between MDR and sensitive $P$ aeruginosa. Our study verifies that the presence of Qac genes alone does not necessarily correlate with increased resistance but Qac genes in combination with other mechanisms might be contributed to the development of cationic antiseptics resistant and the survival of bacteria in toxic environments. Future work should be done to determine the degree to which Qac genes correlate with biocide resistance in other MDR Gram negative bacteria. 


\section{Acknowledgements}

We thank Dr. Hala Mahmoud Hafez, Associate Professor of Clinical and Chemical pathology, Faculty of Medicine, Ain Shams University for providing clinical isolates from the University Hospital Cairo, Egypt. Al-Azhar Univesity, Cairo, Egypt is also acknowledged for providing financial support.

\section{References}

1. Olowe, O.A.; Olayemi, A.B.; Eniola, K.T.; Adeyeba, O.A. Antibacterial activity of some selected disinfectants regularly used in hospitals. Afr J Clin Exp Microbiol 2004; 5: 126-130. DOI: 10.4314/ajcem.v5i1.7365

2. Denyer, S.P.; Hodges, N.A.; Sean, P.; Gorman, S.P. Hugo and Russell's Pharmaceutical Microbiology, $7^{\text {th }}$ edition. UK: Blackwell Science, 2004.

3. McDonnell G.; Russell, A.D. Antiseptics and Disinfectants: activity, action, and resistance. Clin Microbiol Rev 1999; 12: 147-179. DOI: 0893-8512/99/\$04.0010

4. Russell, A. D. Plasmids and bacterial resistance to biocides: a review. J App Microbiol 1997; 82: 155-165. DOI: 10.1046/j.1365-2672.1997.00198.x

5. Mittal, R; Sharma, S; Chhibber, S; Harjai, K. A time course study of production of virulence factors by biofilms of Pseudomonas aeruginosa. Am J Biomed Sci 2009; 1(3): 178-187. DOI: 10.5099/aj090300178

6. de Bentzmann, S.; Plesiat, P. The Pseudomonas aeruginosa opportunistic pathogen and human infections. Environ Microbiol 2011; 13: 1655-65. PMID: 21450006

7. Kumar, R.; Chhibber, S.; Harjai K. A comparative study of clinical and environmental isolates of Pseudomonas aeruginosa in Terms of Quorum Sensing, Outer Membrane Proteins and Their Ability to Cause Urinary Tract Infection. Am J
Biomed Sci 2009; 1(3): 205-214. DOI: 10.5099/aj090300205

8. Kireçci, E.; Kareem, R.D. Antibiotic susceptibility patterns of Pseudomonas aeruginosa strains isolated from various clinical specimens. Sky J Microbiol Research 2014; 2: 13-17. ISSN 2315-876X

9. Cezario, R.C.; De Morais, L.D.; Ferreira, J.C. Nosocomial outbreak by imipenem resistant metallo- B-lactamase producing Pseudomonas aeruginosa in an adult intensive care unit in Brazilian teaching hospital. Enferm Infec Microbiol Clin 2009; 27: 269-274.

DOI: 10.1016/j.eimc.2008.09.009.

10. Kazama, H.; Hamashima, H.; Sasatsu, M. Arai T. Distribution of the antisepticresistance genes qacE and qacE $\Delta 1$ in Gramnegative bacteria. FEMS Microbiol Letters 1998; 159: 173-17. DOI:10.1016/S03781097(97)00563-6

11. Chang, Y.C.; Shih, D.Y.C.; Wang, J.Y.; Yang, S.S. Molecular characterization of class 1 integrons and antimicrobial resistance in Aeromonas strains from foodborne outbreak-suspect samples and environmental sources in Taiwan. Diagnos Microbiol and Infect Disease 2007; 59: 191-197. PMID: 17908616

12. Paulsen, I.T.; Littlejohn, T.G.; Rådström, P.; Sundström, L.; Sköld, O.; Swedberg, G.; Skurray, R.A. The $3^{\prime}$ conserved segment of integrons contains a gene associated with multidrug resistance to antiseptics and disinfectants. Antimicrob Agents Chemother 1993; 37: 761-768. PMID: 8494372

13. Paulsen, I.T.; Brown, M.B.; Skurray, R.A. Proton-dependent multidrug efflux systems. Microbiol Rev 1996; 60: 575-608. DOI: 0146-0749/96/\$04.0010

14. Winn, W.J.; Allen, S.; Janda, W.; Koneman, E.; Procop, G.; Schreckenberger, P.; Woods, G. Koneman's Color Atlas and Textbook of Diagnostic Microbiology, $6^{\text {th }}$ edition. London: Lippincott Williams \& Wilkins, 2006.

15. Clinical and Laboratory Standards Institute, Performance Standards for Antimicrobial Susceptibility Testing: Seventeenth 
Informational Supplement M100-S17. CLSI, PA, USA: Wayne, 2007.

16. Magiorakos, A.P.; Srinivasan, A.; Carey, R.B.; Carmeli, Y.; Falagas, M.E.; Giske, C.G.; Harbarth, S.; Hindler, J.F.; Kahlmeter, G.; Olsson-Liljequist, B.; Paterson, D.L.;. Rice, L.B.; Stelling, J.; Struelens, M. J.; Vatopoulos A.; Weber J.T.; and Monnet, D.L. Multidrug-resistant, extensively drug resistant and pandrug-resistant bacteria: an international expert proposal for interim standard definitions for acquired resistance. Clin Microbiol and Infec 2011; 18: 268-281. DOI: 10.1111/j.1469-0691.2011.03570.x

17. Mazzola, P.G.; Jozala, A.F. Novaes LC, Moriel1 P, Penna TCV. Minimal inhibitory concentration (MIC) determination of disinfectant and/or sterilizing agents. Brazilian J of Pharmaceut Scien 2009; 45, n. 2. DOI: $10.1590 / \mathrm{S} 1984-82502009000200008$

18. Kucken, D.; Heinz-Hubert, F.; Kaukfers, P.M. Association of qacE and qacE $\Delta 1$ with multiple resistance to antibiotics and antiseptics in clinical isolates of Gramnegative bacteria. FEMS Microbiol Letter 2000; 183:95-98. DOI: 10.1111/j.15746968.2000.

19. Wang, C.; Zhan, Q.; Mi, Z.; Huang, Z.; Chen, G. Distribution of the antiseptic-resistance gene qacE delta 1 in 331 clinical isolates of Pseudomonas aeruginosa in China. Journal of Hospital Infection 2007; 66: 93-95. DOI 10.1016/j.jhin.2007.01.012

20. Ghoneim, E.; Awad, S.; Khalil, M. Prevalence of Multi-Drug Resistant Pseudomonas Spp. and Acinetobacter Spp. causing nosocomial infection in intensive care unit (ICU) of national liver institute. Egyptian J Medi Microbiol 2010; 19: No. 1.

21. Mahmoud, A.B.; Zahran, W,H.; Hindawi, G.R.; Labib, A.Z.; Galal, R. Prevalence of Multidrug-Resistant Pseudomonas aeruginosa in patients with nosocomial infections at a university hospital in Egypt, with special reference to typing methods. J Virol \& Microbiol 2013; 13 pages. DOI: $\underline{10.5171 / 2013.290047}$

22. Zafer, M.M.; Al-Agamy, M.H.; ElMahallawy, H.A.; Amin, M.A.; Ashour, M.S.
Antimicrobial resistance pattern and their Beta-lactamase encoding genes among Pseudomonas aeruginosa strains isolated from cancer patients. BioMed Research International 2014; 8 pages. DOI: $10.1155 / 2014 / 101635$

23. Tavajjohi, Z.; Moniri R. Detection of ESBLs and MDR in Pseudomonas aeruginosa in a tertiary-care teaching hospital. Iranian Journal of Clinical Infectious Diseases 2011; 6: 1823. ISSN: 20081081

24. Gad, G.F.; El- Domany, R.A.; Zaki, S.; Ashour, H.M. Characterization of Pseudomonas aeruginosa isolated from clinical and environmental samples in Minia, Egypt: prevalence, antibiogram and resistance mechanisms. J Antimicrob Chemother 2007; 60:1010- 1017. DOI: 10.1093/jac/dkm348

25. Jones, I.G.; Midgley, M. Expression of a plasmid borne ethidium resistance determinant from Staphylococcus in Escherichia coli - evidence for an efflux system. FEMS Microbiol Letters 1985; 28: 355-358.

DOI:10.1111/j.15746968.1985.tb00820.x

26. Orrett, F.A. Antimicrobial susceptibility survey of Pseudomonas aeruginosa strains isolated from clinical sources. J Natl Med Assoc 2004: 96:1065-69. PMC2568484

27. Romao, C.; Miranda, C.A.; Silva, J.; Clementino, M.M.; de Filippis, I.; Asensi, M. Presence of qacE delta 1 gene and susceptibility to a hospital biocide in clinical isolates of Pseudomonas aeruginosa resistant to antibiotics. Current Microbiol 2011; 63: 16-21. DOI: 10.1007/s00284-011-9934-0

28. Mitiku, M.; Ali, S.; Kibru, G. Antimicrobial drug resistance and disinfectants susceptibility of Pseudomonas aeruginosa isolates from clinical and environmental samples in Jimma University specialized hospital, Southwest Ethiopia. Am J Biomed and Life Scien 2014; 2: 40-45. DOI: 10.11648/j.ajbls.20140202.12

29. Bratu, S.; Quale, J.; Cebular, S.; Heddurshetti, R.; Landman, D. Multidrugresistant Pseudomonas aeruginosa in Brooklyn, New York: molecular epidemiology and in vitro activity of 
polymyxin B. Eur J Clin Microbiol Infect Dis 2005; 24:196-201. DOI: 10.1007/s10096005-1294-X

30. Yetkin, G.; Otlu, B.; Cicek, A.; Kuzucu, C.; Durmaz, R. Clinical, microbiologic, and epidemiologic characteristics of Pseudomonas aeruginosa infections in a University Hospital, Malatya, Turkey. Am J Infect Control 2006; 34:188-92. DOI:10.1016/j.ajic.2005.11.010

31. Corona-Nakamura, A.L.; Miranda-Novales, M.G.; Leanos-Miranda, B.; Portillo-Gómez, L.; Hernández-Chávez, A.; Anthor-Rendón, J.; Aguilar-Benavides, S . Epidemiologic study of Pseudomonas aeruginosa in critical patients and reservoirs. Arch Med Res 2001; 32: 238-42. DOI: 10.1016/S01884409(01)00267-3

32. Gencer, S; Ak, O.; Benzonana, N.; Batirel, A.; Ozer, S. Susceptibility patterns and cross resistances of antibiotics against Pseudomonas aeruginosa in a teaching hospital of Turkey. Ann Clin Microbiol Antimicrob 2002; 1:2. DOI:10.1186/14760711-1-2

33. Oni, A.A.; Nwaorgu, O.G.B.; Bakare, R.A. The discharging ears in adults in Ibadan, Nigeria; causative agents and antimicrobial sensitivity pattern. Afr J Clin Exp Microbiol 2002; 3: 3-5. DOI:10.4314/ajcem.v3i1.7341

34. Weber, D.J.; Rutala, W.A. Use of germicides in the home and the healthcare setting: is there a relationship between germiciden use and antibiotic resistance? Infec Control Hosp Epidemiol 2006; 27:1107-1119. PMID: $\underline{17006819}$

35. Ogbulie, J.N.; Adieze, I.E.; Nwankwo, N.C. Susceptibilty pattern of some clinical bacterial isolates to selected antibiotics and disinfectants. Polish J Microbiol 2008; 57: 199-204. PMID: 19004240

36. Alabi, O.S.; Sanusi, E.A. Efficacy of three disinfectant formulations against multidrug resistant nosocomial agents. Afr J Cln Exper Microbiol 2012; 13: 178-182. DOI:10.4314/ajcem.v13i3.8

37. Iroha, I.R.; Oji, A.E.; Nwosu, O.K.; Amadi, E.S. Antimicrobial activity of Savlon, Izal and Z- germicide against clinical isolates of
Pseudomonas aeruginosa from hospital wards. Eur J Dent Med 2011; 3:32-35. DOI: 10.3923/ejdm.2011.32.35

38. Bouzada, M.L.; Silva, V.L.; Moreira, F.A.; Silva, G.A.; Diniz, C.G. Antimicrobial resistance and disinfectants susceptibility of persistent bacteria in a tertiary care hospital. J Microbiol Antimicrob 2010; 2: 105-112. ISSN 2141-230

39. Jones, R.N.; Kirby, J.T.; Beach, M.L. Geographic Variations in Activity of BroadSpectrum Lactams against Pseudomonas aeruginosa: Summary of the Worldwide SENTRY Antimicrobial Surveillance Program (1997-2000). Diagnosis Microbiol Infect Dis 2002: 43: 239-243. DOI:10.1016/S0732-8893(02)00390-5

40. Tennent, J.M.; Lyon, B.R.; Midgley, M.; Jones, I.G.; Purewal, A.S.; Skurray, R.A. Physical and biochemical characterization of the qacA gene encoding antiseptic and disinfectant resistance in Staphylococcus aureus. J Gen Microbiol 1989; 135: 1-10. DOI: $10.1099 / 00221287-135-1-1$

41. Rouch, D.A.; Cram, D.S.; Diberardino, D.; Littlejohn, T.G.; Skurray, R.A. Effluxmediated antiseptic resistance gene qacA from Staphylococcus aureus - common ancestry with tetracycline-transport and sugar-transport proteins. Molecular Microbiol 1990; 4: 2051-2062. DOI: 10.1111/j.13652958.1990.tb00565.x

42. Littlejohn, T.G.; Paulsen, I.T.; Gillespie, M.T.; Tennent, J.M.; Midgley, M.; Jones, I.G.; Purewal, A.S.; Skurray, R.A. Substrate specificity and energetics of antiseptic and disinfectant resistance in Staphylococcus aureus. FEMS Microbiol Letters 1992; 95: 259-266. PMID: 1526458

43. Jaglic, Z.; Cervinkova, D. Genetic basis of resistance to quaternary ammonium compounds - the qac genes and their role: a review. Veterinarni Medicina 2012; 57: 275281. ISSN 1805-9392

44. Lévesque $\mathrm{C}$, Piche L, Larose C. PCR mapping of integrons reveals several novel combinations of resistance genes. Antimicrob Agents Chemother 1995; 39: 185-191. DOI: $\underline{0066-4804 / 95 / \$ 04.0010}$ 